\title{
Urban Processes in Zagreb. Residential and Commercial Developments
}

\author{
Anđelina Svirčić Gotovac, Jelena Zlatar
}

In the post-socialist and transition period, Croatia and especially its capital city Zagreb have experienced many physical transformations of space but, most of all, remarkable social changes. For example, socially-oriented housing construction planned and co-financed by towns in Croatia is in a very unfavourable position compared to private housing construction, especially on the outskirts of towns. This benefits neither towns nor their residents, but rather only those urban actors interested in the development of capitalism. In recent years, there has been a lot of building in the city core and on the outskirts of Zagreb, which is not well integrated into the existing urban structure, image or skyline of the city. There is also a major problem of insufficient primary and secondary infrastructure in the new housing estates. The current situation in the planning process is characterized by conflict and lack of balance between powerful political and economic actors and less powerful professional and civil actors. Experts of various profiles often point out that ignoring the process of planning means irreparable long-term damage to the space. Such incongruous transformations show the absence of comprehensive urban planning and urbanism.

Key words: urban processes, urban actors, transition context, city transformations, Zagreb

\section{Urbani procesi u Zagrebu. Stambena i poslovna gradnja}

Cjelokupni je prostor Hrvatske u postsocijalističkom i tranzicijskom razdoblju doživio brojne i značajne promjene, i u smislu fizičkih transformacija, ali ponajviše onih socijalnih. Primjerice socijalna stanogradnja koju planiraju i sufinanciraju gradovi u Hrvatskoj u vrlo je nepovoljnom položaju prema stanogradnji privatnog tipa, pogotovo na rubovima gradova. Takva situacija nije povoljna za građane i grad, već samo za one urbane aktere koji podržavaju kapitalistički razvoj grada. Posljednjih godina pojavljuje se izgradnja u centru i na rubovima grada koja se ne uklapa u postojeću urbanu strukturu i njegovu vizuru. Prisutan je i problem neadekvatne primarne i sekundarne infrastrukture u novim naseljima. Trenutačnu situaciju u procesu planiranja karakteriziraju sukobi i neravnoteža između političkih i ekonomskih aktera na jednoj strani te stručnih i civilnih aktera na drugoj. Stručnjaci različitih profila upozoravaju kako ignoriranje procesa planiranja dugoročno ostavlja nepopravljivu štetu u prostoru te kako takve transformacije grada govore o nepostojanju urbanizma.

Ključne riječi: urbani procesi, urbani akteri, tranzicijski kontekst, transformacija grada, Zagreb 


\section{INTRODUCTION}

In the post-socialist period, since the 1990s onwards, major social, political and economic changes have happened in Croatia and especially in Zagreb, the capital city. The champions of these changes are new social actors, primarily economic actors (e.g. property investors) and political actors (e.g. town mayors). In the past, under socialism, their influence was not strong. The state was the most powerful actor. "In Croatia, the existing social context (transition and post-socialism) makes social actors increasingly important. New social changes affect the activities and behaviour of new and old actors. Their importance and their activities cannot be separated from the process of restructuring of modern society today. Both the urban and rural space of Croatia has undergone significant physical transformations in the transition period, but social changes are even more relevant" (Svirčić Gotovac, 2012,13-14).

These changes are clearly visible in urban planning. During socialism, urban planning was based on well-defined, long-term strategies. Post-socialism is characterised by a completely different attitude to space: no strategic, long-term planning, no careful consideration of spatial development. The consequences are evident. "Socialism is believed to have been one of the most constructive periods in the urban development of Zagreb. Not only regarding the quantity of housing construction but also its quality and the quality of life of Zagreb's citizens" (Jukić et al., 2011). The new capitalist system and its market laws prefer to make a quick profit on investment, most of which is private. Politicians take the side of the investors rather than that of experts or civil actors. The outcome is often thoughtless and unfortunate intervention in space, in suburban areas and in city centres. This is visible in both residential and commercial construction. "Consequently, land-use planning at the municipal level is characterized by the prevalence of ad hoc political decisions and not long-term strategic visions. Also, the development control is weak, and there is a 'laissez-faire' approach to the city development" (Hamilton et al., 2005, 475).

In Croatia today, spatial development is neglected and there is insufficient participation of citizens in public and political life. People do not take an active part in solving problems regarding their immediate living environment. "The Act on Spatial Planning and Construction does not precisely define the role of citizens and their participation. The problem is also that the interpretation of existing regulations does not always benefit the citizens or insist on their transparent participation. Only minimum standards of legal procedure are satisfied" (Toš and students, 2012, 91). In present-day Croatia there is a public presentation of potential projects and a public hearing, which normally lasts for two weeks. There is no response to public comments. which suggests that people do not have any real influence. In addition, a public hearing is not sufficiently effective. Other steps should precede it, such as information about the stages of the project along with the professionals' views on the project (its advantages and drawbacks). For the public, that would mean a longer period of involvement resulting in a more democratic decision-making process. More participation can affect people's living conditions at the local level and that is connected with their total quality of life.

In the following sections of the paper we present the theoretical context, methodology, principal goals and results of the research of transformation processes in various parts of Zagreb (in the city centre and on the outskirts). After an in-depth analysis of research results, we draw a conclusion in which we point out the most relevant findings about the examined transformation processes. 


\section{THEORETICAL CONTEXT}

We have already mentioned that under the existing globalization and transition circumstances, spatial transformations in Croatia are happening with almost no citizen participation. Public interest is often neglected and private interest is promoted. Such relations among different social actors in the process of spatial planning show the conflict and lack of balance between powerful (usually political and economic) actors and less powerful (mostly professional and civil) actors. So, different actors come into conflict and compete to achieve their goals within the social system. According to Parsons (1966), for example, power is "a means of attaining goals" but at the same time it ensures the imperative reproduction of the social system. Trying to prove that each subsystem, which makes up the social system, has the same logical structure, meets the same requirements and complies with the same principles, Parsons compares power with money. In this context, he calls it "a means of circulation" within the "political subsystem" in the same way that money is a means of circulation in the "economic subsystem". Money, power and influence are therefore characteristic mechanisms of the social system. Parsons also suggests we accept "power" as a "game" from which both sides can make a profit. Power becomes a means of achieving individual goals because society members agree to leadership positions (according to Kuvačić 1990, 62). Numerous actors, urban actors among them, from different parts of the social system are driven towards certain goals. In the end, their activity and their goals depend on their power within the system.

"Urban phenomenon comprises a complex set of actors and each type of society and each type of urban society means a power hierarchy of actors. A different power structure for a different system" (Bassand, 2001, 86). It is precisely the power of a specific actor which defines how much difference their activities will eventually make to space. "In many post-socialist countries neo-liberal thinking is characterized by central governments giving a low political priority to physical planning, regional development and housing policy. A comprehensive national strategy and coherent regional policies do not exist; there are only local and regional government reforms and disputes regarding new legislation (Sykora, 1994; Dimitrovska Andrews and Ploštajner, 2000; Pichler-Milanović, 2001). A hierarchy of power is natural in society; however, power manipulation is different from one society to another. In the post-socialist society the inherited values and the capitalist economy have not equally empowered all social actors; already powerful political and economic actors have become stronger and previously weak actors (professionals and civil society) weaker. The problem is that their interaction significantly affects various urban and rural development processes in Croatia, for instance, the quality of life.

The period immediately after the Homeland War, the 1990s, was characterized by slow economic recovery and small scale, mostly residential building, initiated by private investors as new economic actors (Jukić et al., 2011, 43). Since 2000, commercial building has increased because investors have gained more power and influence. But the lack of planning and method, random building, and disregard for the general appearance of the city has had bad results: old and new buildings do not live in harmony together. This is especially obvious in recently built (a) business towers, (b) shopping malls and (c) underground public garages. Instead of preservation and rehabilitation of a mature, tight urban fabric, new interpolations and excessive building have led to urban structure densification and consequently to various infrastructure problems, and legal and economic problems, resulting in urban chaos in the city (Zlatar, 2014, 154).

Many authors (Seferagić, 2005; Hodžić, 2005; Čaldarović, 2011; Vujović, 2005; Svirčić Gotovac, 2010; Zlatar, 2013; Pušić, 2015) argue that in the post-socialist countries spatial development is mostly shaped by the economic sector (investors, developers), because of their power and influence. The problem is that they use this power for their own, short-term interests, which 
do not correspond with public interest or long-term city development strategies. They would not, however, enjoy so much freedom in their activities if they did not have the support of political actors, i.e. the mayor and the local government. Largely due to the former socialist system, citizens are not well-informed about their rights; on the other hand, local political elites and professionals are not in the habit of acknowledging public opinion (Vujović, 2012, 58). In such circumstances it is not surprising that commercial construction is encouraged and residential construction neglected or left in the hands of private investors who build flats, but not the neighbourhood, the living environment. "So Zagreb has a new 'business district' (the City) which is so similar to others all over Europe that it is not easy to distinguish among them" (Čaldarović, 2011, 40). Here we speak about the cityzation of space, which means converting the complex and rich city life into something less - business and commerce (Zlatar, 2013). The phenomenon of cityzation can be best experienced in the broader city centre, in Radnička Street and Heinzelova Street, which are crammed with new, modern office buildings with a new social class of business people employed and working in them. A host of negative consequences have followed from the absence of planning in Zagreb since 2000: lower quality of life in new housing estates, poor infrastructure in the new estates, uneconomical planning resulting in long-term damage to the city, changes of the Master Plan favouring property investors, and the like (Zlatar, 2014, 154.)

Housing estates built during the transition period can hardly be compared to the housing estates from the socialist period (the 1960s, the 1970s and the 1980s) in New Zagreb or the greater city area. ${ }^{1}$ Beside blocks of buildings, those estates had the accompanying infrastructure necessary for the everyday life of their residents (public utilities, kindergartens, playgrounds, green areas, public transport stations) at both the primary and secondary level. Basic urban activities could be successfully carried out in most estates built during socialism, whereas today we are witnessing problems with inadequate and insufficient infrastructure on the new estates whose residents, in search of different services, often put pressure on already overstretched facilities in older estates (Svirčić Gotovac, 2015). The exception are the new POS estates (the Programme of Subsidized Housing Construction), built by the city as a type of social housing, cheaper and more available to people, which was the original intention. ${ }^{2}$ However, out of nine previously planned estates, the City of Zagreb has built only three so far. They have the necessary infrastructure in their immediate environment but it sometimes happens that new residential buildings erected by private investors in their neighbourhood do not have all services and facilities so people have to share the existing ones (e.g. POS Špansko-Oranice). In the following sections of the article these observations about residential and commercial development in Zagreb in the last few decades will be confirmed by the results of research carried out from 2007 until 2015.

\section{METHODOLOGICAL APPROACH}

Beside the complexity of urban processes, they are also interdisciplinary. Our research of these processes is theoretically and methodologically limited to the context of urban sociology. It

\footnotetext{
${ }^{1}$ Seferagić $(1988,28)$ defines new housing estates in socialism as residential zones of collective housing, accompanied by basic urban infrastructure elements, surrounded by major roads, built relatively quickly on the edge of big towns $t$ and with the intention of providing everything for daily life at the local level.

${ }^{2}$ According to the Agency for Government Real Estate (APN in Croatian), the POS programme was initiated to enable Croatian citizens to solve their housing problems under conditions more favourable than those on the market: housing loans can be obtained without guarantors, the average interest rate is $2.9 \%$, incidental expenses are minimum, the repayment period is up to 30 or 31 years, in case of a one-year grace period (www.apn.hr).
} 
examines the structure and power of urban actors in the transition period as well as the effects of these processes on the quality of life of the urban population.

The paper presents some of the most important results obtained from research projects recently carried out at the Institute for Social Research in Zagreb ${ }^{3}$, e.g. Actors of social changes in space (2007-2013) and The quality of living in Zagreb settlement network (2014-2015). We used both qualitative (semi-structured interviews) and quantitative (surveys, questionnaires) methods, which ensured a deep insight into the examined topics and also their broad spatial coverage. Semi-structured interviews were conducted between 2008 and 2011 and there were 60 of them in total. Our respondents belonged to various types of social actors (Bassand, 2001) - they were professional, civil, economic and political actors. The survey research was done in 2014 on a target sample of 308 respondents who live in new housing estates (built after the 1990s) in Zagreb settlement network (in the City of Zagreb and in Zagreb County). In Zagreb, 17 locations were sampled plus 6 more, 2 in each satellite town (Velika Gorica, Zaprešić and Samobor), 23 locations in total (Svirčić Gotovac, 2015).

The main goal of the paper is an in-depth analysis of urban processes in various parts of Zagreb because they have had different effects on different parts of the city. How attractive certain parts of the city are depends on transition and globalization processes, such as de-industrialization and re-urbanization. In transition countries, as can be seen in Zagreb in the last two decades, residential areas and commercial zones of the city do not have the same value or attractiveness. There is a widening gap between them. Residential areas, being unprofitable, are pushed further and further to the periphery of the city, whereas commercial zones are drawn closer and closer to the city centre, which becomes crammed with shopping malls, underground public garages etc.

A research hypothesis or assumption is that the most satisfying and also the most available housing in Zagreb is on the periphery of the city, whereas the city centre and a wider city area are most attractive commercially. Another hypothesis is that new building projects in Zagreb were mostly carried out without careful and strategic urban planning, supported by political actors and city authorities.

\section{RESEARCH RESULTS}

\section{Urban processes in the centre of Zagreb}

Since the 1990s, the role of private investors in most countries has become increasingly important and they have made large financial investments. It also means they have made major decisions about the appearance of city centres and suburban areas. Processes such as urban renewal, regeneration and gentrification have grown stronger in Zagreb since the 1990s. "Earlier the process of gentrification was generally associated with the real estate market of developed countries and their leading cities (the so-called command-centre cities). Today, however, it is becoming a global process and an urban strategy going beyond liberal urban policy or sporadic and local occurrence" (Smith, 2002, 427). Attractive real estate in the city centre has made gentrification possible and has revived building there, with uneven involvement of spatial actors. Shopping centres and underground garages have been built near the city centre. By allowing traffic in the city centre rather than reducing the number of cars, Zagreb is not following the trends in developed European cities. Experts and citizens take part in these city changes only marginally while other actors - investors -

\footnotetext{
${ }^{3}$ These projects resulted in two $\mathrm{PhD}$ theses, collections of academic papers from international conferences, an author's book and numerous articles related to urban processes in Zagreb and its surroundings in the last two decades.
} 
make a maximum profit. In the process of urban renewal the role of the state has weakened and private investors play a prominent role. "Not only does 'urban regeneration' represent the next wave of gentrification, planned and financed on an unprecedented scale, but the victory of this language in anaesthetizing our critical understanding of gentrification in Europe represents a considerable ideological victory for neoliberal visions of the city" (Smith, 2002, 446).

Since the state and the city government play an inadequate role in the renewal and revitalization of the city centre, new actors have become extremely powerful and responsible for its future appearance. However, they do not treat it with respect and do not care about the historical and urban identity of the city. Even some protected parts of the old city core have been radically altered and expanded, the changes usually accompanied by discordant opinions of experts and politicians. Flower Square in Zagreb (Fig. 1) is a Lower Town protected architectural unit in the heart of the city, where a multifunctional centre was built in 2010 in spite of strong protests coming from experts and citizens (exclusive flats, shopping mall, underground garage). The idea was to attract the wealthy members of society to live there. This has been only partially achieved, while the public garage and the shrinking pedestrian zone have inflicted a considerable blow on the historical city core. This is also an example of short-term economic interests of an investor supported by the city authorities. "Although gentrification is by definition a re-structuring of population, in Zagreb gentrification has some special characteristics because the (upper) middle-class who lived in the city centre before is being replaced by the new upper middle-class, the wealthiest segment of population or the elite. The poor have never lived in the city centre anyway, except in the most

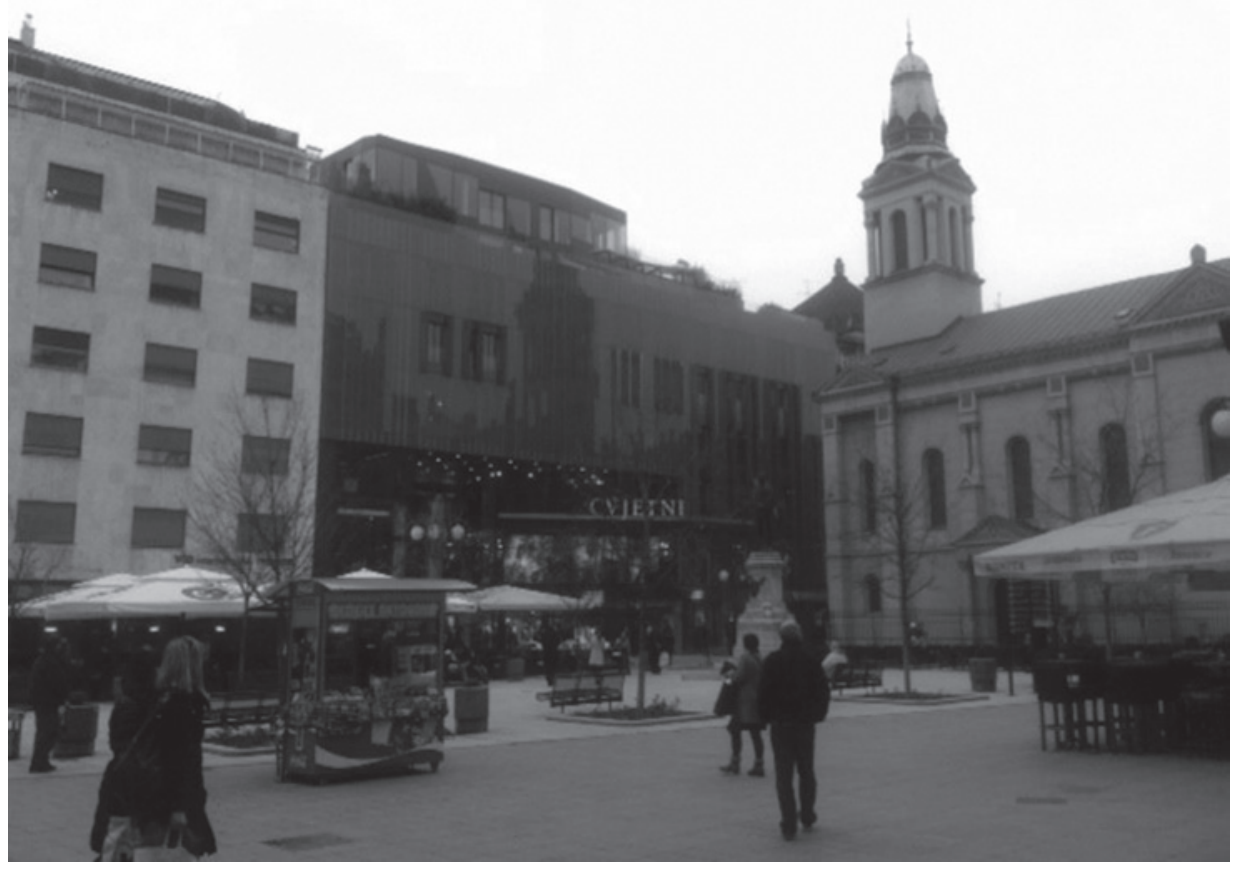

Fig. 1 Shopping mall Cvjetni in Flower Square (Zagreb city core)

Sl. 1. Trgovački centar na Cvjetnom trgu u zagrebačkoj gradskoj jezgri

Source: Photo by the authors 
derelict parts. The centre has always been occupied mostly by the upper class" (Svirčić Gotovac, 2010, p.216). So, gentrification of Flower Square is not necessary in terms of population re-structuring. There are numerous other dilapidated parts of the city centre where gentrification and urban renewal would be a lot more desirable.

However, the most remarkable transformations of urban space have happened on the edge of the city because of numerous open possibilities there (commercial, business and residential developments).

\section{Residential developments}

In the twenty years of transition we have witnessed a lot of residential and commercial construction. In new densely populated housing estates in the wider city area, but also in the City of Zagreb, the quality of life of residents is rather low. Private investors took little care about technical or social infrastructure in the new settlements. City authorities, on the other hand, did not demand their help with the necessary infrastructure for everyday life of residents (schools, kindergartens, shops, health and culture centres, playgrounds, parks, green areas) when giving out municipal land plots. And the city itself often could not finance the complete infrastructure so it is not unusual that it does not meet the citizens' needs today. Housing has changed in the period of transition, for better and for worse. The most obvious change is a large number of new flats and housing developments initiated by private investors and very few by the city. Social housing subsidized by the state (city) is currently stagnating, although in the last few years new projects, offering flats at favourable prices, have been considered. More of these projects have been planned than completed and so they remain shadowed by private investment.

New housing estates are mostly located in the suburban area of Zagreb, which is more profitable than the wider region of the settlement network. Podsljeme, an attractive city district in the north of the city, for example, has failed to keep pace with city zones in the east, west and south, where private investors have financed new housing developments. Residential developments have often sprung up on relatively small land plots. Although people live in new flats, there are no adequate facilities in their immediate neighbourhood. The housing quality has been neglected: a large number of flats without the elements of infrastructure, such as kindergartens, schools or parks. Residents of new estates, in order to satisfy basic needs, have to use services in older estates, which, predictably, puts too much pressure on the existing infrastructure. Kindergartens, schools and local health centres are over-crowded. The reason for this is bad urban policy. Private investors have never been asked to ensure the appropriate infrastructure. So the problem of infrastructure is passed on to the city, which often does not have sufficient financial means and therefore puts everything off or builds very selectively. Another difficulty are unresolved problems of private ownership: first a new estate is built and only later, when the city purchases land from the owners, comes the question of facilities and the design of public space. "There are only two housing estates, Špansko and Sopnica-Jelkovec, which are exceptions to these practices, while others (Vrbani III, Oranice, Dubravica-Karažnik...) were built without detailed plans or appropriate supervision" (Jukić et al., 2011, 109). Since 2000 there has been excessive residential development in Zagreb, which now has a surplus of 20,000-40,000 flats. Most of these flats were built merely to bring profit while the housing quality was irrelevant at the time of building and remains irrelevant even today.

40,000 new flats were built in Zagreb from 2001 to 2008. "There are about 20,000 new flats on sale on the real estate market now, plus some old flats. A lot of people live in the parts of town where there are no basic services, no local employment, no green areas, sport or recreation facilities" (ZagrebPlan, 2013, 127). At the same time, paradoxically, most people cannot afford to 
buy new flats because of exorbitant prices per square metre. It is therefore clear that the principal goal has not been achieved: the housing quality is not satisfactory. European Charter on Housing states that "controlling the expansion of suburban and urban zones should become an important goal for the Community if sustainable development is to be maintained" (Article 5, Section 2, European Housing Charter). Suburban zones of Zagreb are hardly good examples of sustainable development.

The Sopnica-Jelkovec housing estate (Fig. 2), which is an example of social housing, has long suffered a negative public perception (far from public transport, poor facilities and services, low-income families, marginal social groups, mostly the Roma, who were allocated flats by the City). Today the situation is better because of improved infrastructure, new facilities (kindergarten, primary and secondary school, health centre, parks, playgrounds). The City offers flats to rent at attractive prices, which is a new practice, especially convenient for young families ${ }^{4}$. The 2014 research about the quality of living in new estates in Zagreb reveals that the most contented residents live in the POS estates (especially Špansko-Oranice and Sopnica-Jelkovec), which satisfy both primary and secondary level of neighbourhood infrastructure and facilities, unlike many other estates. It is true, however, that the negative image still persists, but the model of public rental housing that intensified in 2014 has made the estate more respectable and desirable.

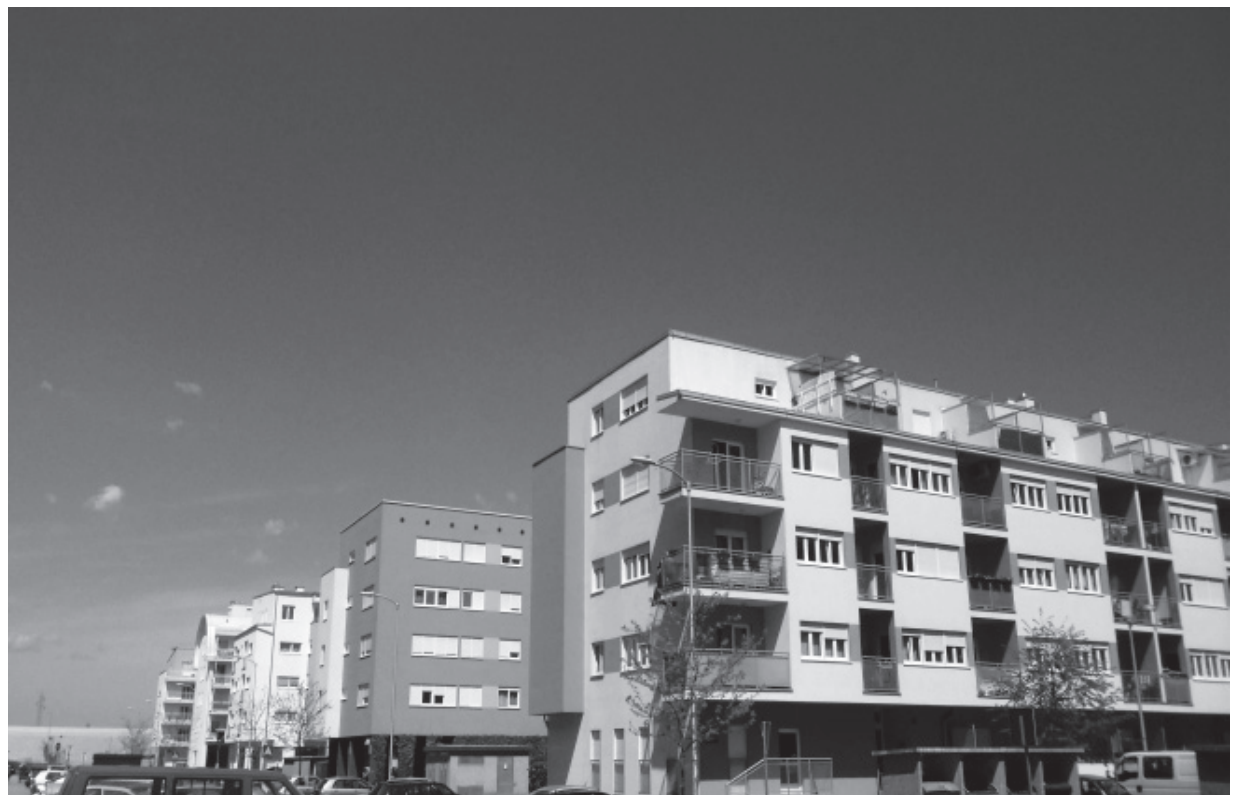

Fig. 2 Sopnica-Jelkovec housing development

Sl. 2. Novostambeno naselje POS-a Sopnica-Jelkovec

Source: Photo by the authors

\footnotetext{
${ }^{4}$ According to the information from print media, e.g. Večernji list and Jutarnji list, in 2014 the rent was accept able for the majority of residents, especially young families. The price of 20 kuna per square metre, specified by the Agency for Government Real Estate (APN) attracted a significant number of new residents. Here is an example from Jutarnji list: "300 flats from $59.88 \mathrm{~m} 2$ to $155.49 \mathrm{~m} 2$ will be offered for rent to citizens at $€ 160$ per month for bigger flats and €94 per month for smaller flats (up to 60m2)" (Jutarnji list, 26th August 2014). Such rents are much more favourable than housing loans, which most people cannot afford.
} 
In Zagreb today residential building is predominantly the result of private enterprise. So, in spite of the fact that Sopnica-Jelkovec has certain problems with its negative image, other POS estates (Vrbani III and Špansko-Oranice) are very well accepted among the residents of Zagreb. They are more affordable and desirable than private and commercial types of estates and that goes to show that in Zagreb and in the whole country there is no social housing for the majority of inhabitants, but only for the most vulnerable social groups. The state and local governments should make a greater effort to provide housing for most people so that private initiative does not continue its leading role in the housing sector. Although the situation is similar in most post-socialist countries, this trend results in the lower quality of life for most residents.

New urban and suburban housing estates offer little beside brand-new (often low quality) flats. There are no facilities and services that improve the quality of housing. People are forced to use primary and secondary infrastructure in the neighbouring estates, which may be 30 or more years old and the infrastructure needs to be rebuilt. So, people from new housing estates (Lanište, Lanište-Jaruščica, Blato) have to use kindergartens, schools or health centres in the oldest New Zagreb estates (Remetinec, Savski Gaj), which puts additional pressure on the 1960s infrastructure. Similarly, people move out of the attractive Podsljeme zone in the north of the city, unable to meet their elementary needs. It is evident that the quality of housing still does not match the amount or quality of building work and there is a lot more to be done for the satisfaction of citizens. The City model of public-private partnership and its potential could have been much better used in urban planning and housing development, but no remarkable results have been achieved. ${ }^{5}$ The city authorities frequently refer to this particular model, well recognized and successful in Europe. It is used in various projects where investors make a profit but also provide useful services and improve the housing quality of citizens. In Croatia, however, because of the crisis in urban planning, developers are offered locations which are not economically attractive for the city and so they become the sole beneficiaries of the partnership. The city authorities fail to realize that the model has been unsuccessfully applied as it does not benefit the citizens of Zagreb.

\section{Commercial developments}

Beside residential construction in suburban areas, urban transformations are also visible in commercial developments: new business zones, high-rise office blocks (Fig. 3) and shopping malls with underground garages. Commercial developments are the most visible and damaging for public space. The consequences are the shrinking of public space and problems with infrastructure. During socialism, business towers were built on vacant land. Today they are built in already crowded areas. Such examples are the Euro Tower, Zagreb Tower and Sky Office Tower. They demonstrate the power, social status and capital of developers by imitating cities in the west. The process of westernization of towns is visible in Zagreb, especially in commercial developments. The main difference between the Vienna checklist $t^{6}$ and the international workshop "Skyscrapers in Europe" in Zagreb ${ }^{7}$ is the (non)existence of criteria and regulations for high-rise projects, their locations or standards. "In Zagreb, high-rise business towers are incompatible with the existing infrastructure and cause traffic congestion. Their building standards are low, in compliance with developers'

\footnotetext{
${ }^{5}$ The term refers to the co-operation between big private investors (often corporations) and the local authorities. The partnership has become quite common recently (Carmon, 1999).

${ }^{6}$ This list contains key guidelines for high-rise projects in the Austrian capital.

${ }^{7}$ The workshop took place on 6th and 7th May 2004. It was organized by the Municipal Bureau of Urban Planning and Environmental Protection. The purpose was to define locations and standards for high-rise projects in Zagreb.
} 
requests. They often intrude in the urban context. Professionals and citizens are insufficiently informed about the projects. Even their profitability remains uncertain" (Zlatar, 2013, 120). So business towers are yet another example of urban transformations dictated by private investment.

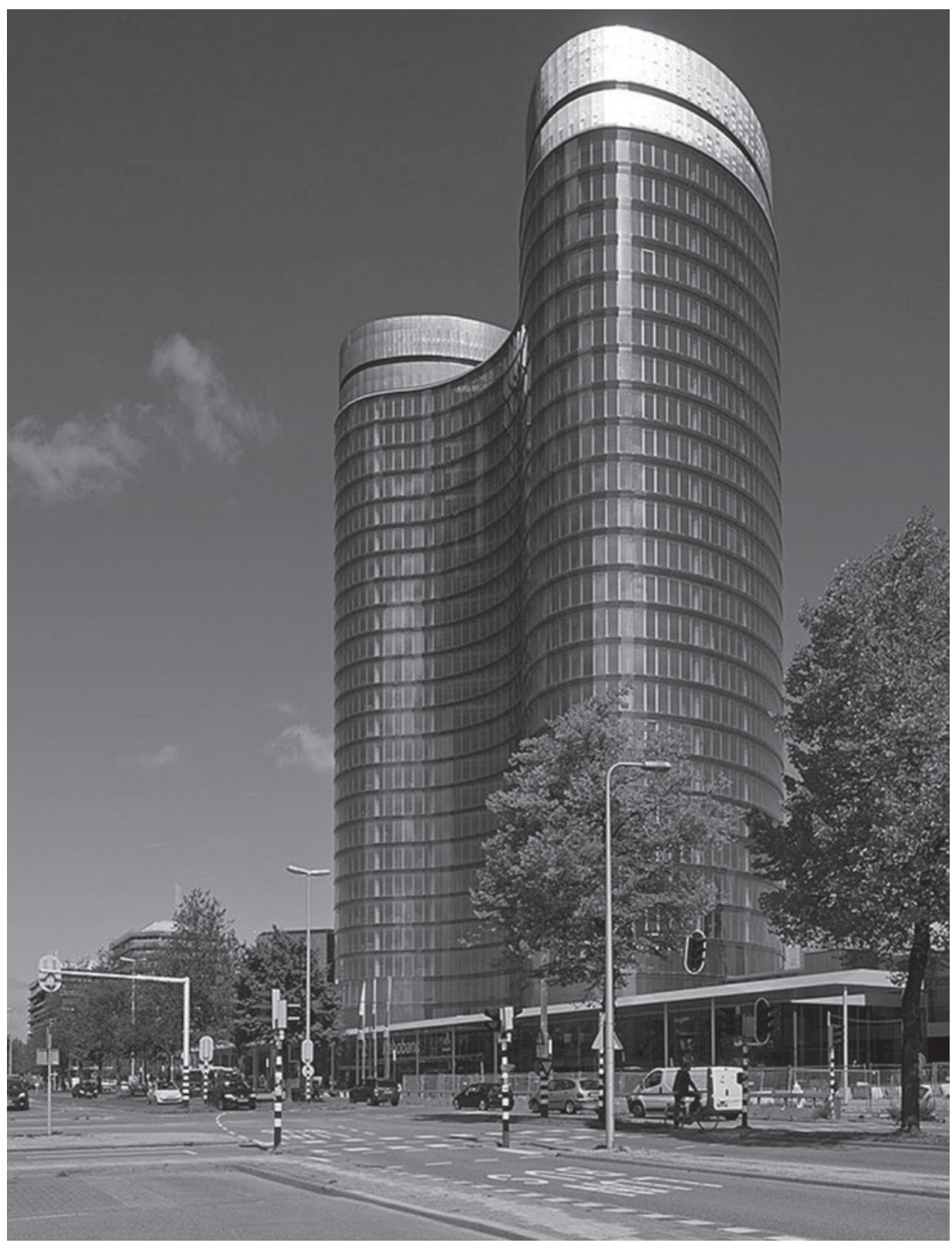

Fig. 3 The latest business tower Sky Office on the west side of the city Sl. 3. Novi poslovni toranj Sky Office na zapadnoj strani Zagreba Source: http://photos.wikimapia.org/p/00/03/65/46/82_full.jpg 
The situation is similar in the so-called Zagreb City in Radnička Street, which has witnessed extensive business and financial development in recent years. The space is filled with business architecture (new, modern materials for the new social class of business people). "Foreign and domestic companies have headquarters in new offices. Financial institutions (banks, insurance companies), IT companies, mass media, transport, commerce - in short, tertiary and quarterly sectors" (Sić, 2007, 7). But the future of the City looks uncertain. "The new central business district has not been spatially defined yet. New buildings are built in a large area, the core of which is yet to be formed" (Sić, 2007, 8).

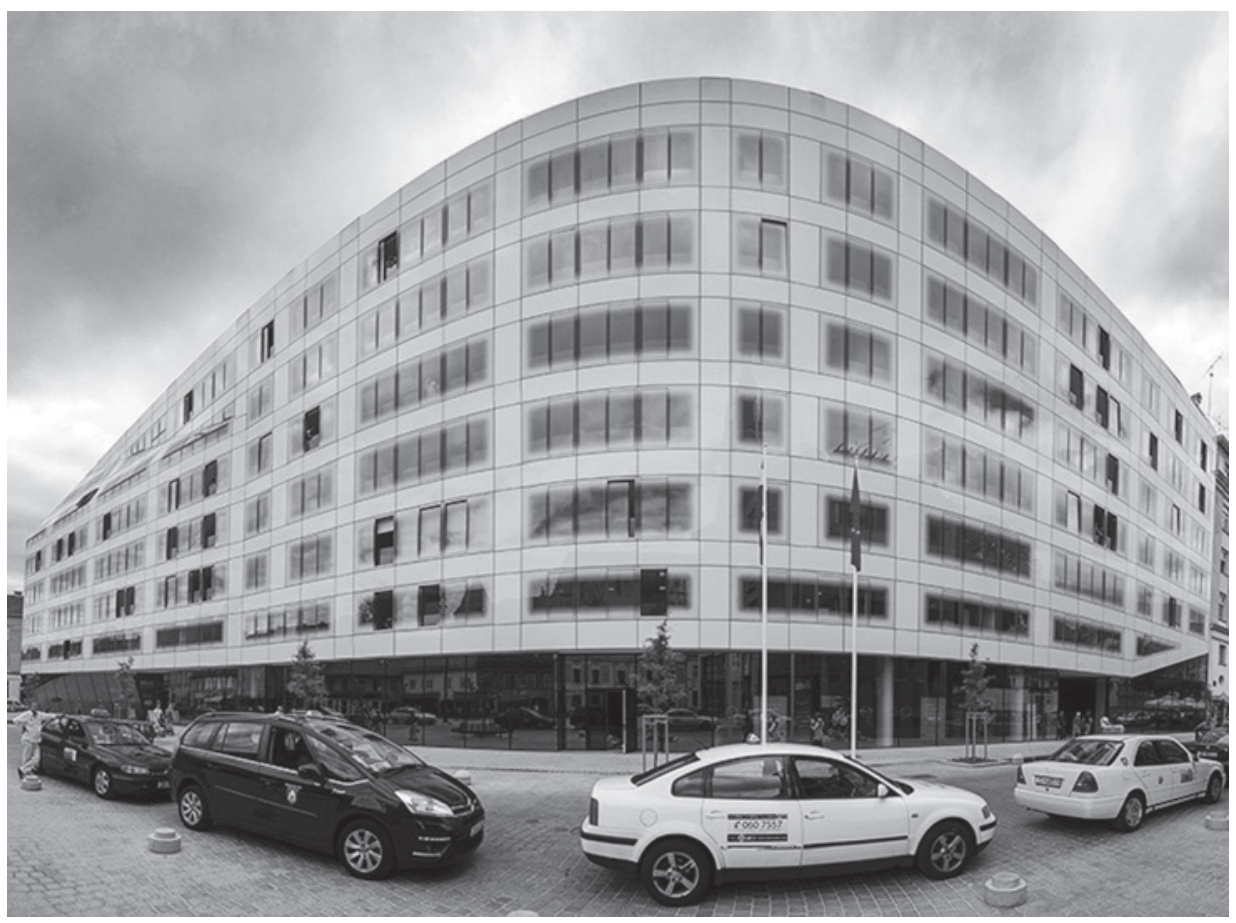

Fig. 4 Ban Center in Zagreb city core

Sl. 4. Ban centar u zagrebačkoj gradskoj jezgri

Source: http://foto.drusany.com/wp-content/uploads/2013/07/Ban-centar-Panorama.jpg

Shopping malls are yet another example of commercial developments. In Zagreb there are a lot of them in the city centre and on the outskirts. Malls are usually built on land which is purchased cheaply with the infrastructure already there. There are eight shopping malls ${ }^{8}$ in the city centre today and a lot more on the outskirts, both multifunctional and specialized malls (Fig. 4). All of them are the results of private developers' initiatives and occupy attractive locations in the city centre or in cheaper suburban areas (Fig. 5). They are also the result of the consumerism in which Zagreb indulged in the 1990s. Some authors call them "cathedrals of consumption" (Gregson, 1995). They are often built randomly, without proper planning, initiated by investors in a powerful

\footnotetext{
${ }^{8}$ Importanne centre (1994), Rotonda Centre (1994), Importanne Gallery (1999), Centre Kaptol (2000), Branimir Centre (2003), Cascade (2009), Centre Cvjetni (2011) and Ban Centre (2013).
} 
alliance with the city authorities. Consumption dominates in the city centre while other functions (culture, history) are diminished. ${ }^{9}$ This becomes pseudo-public space (Voyce, 2006) in which people spend their free time in a new way. The problem is that, after some time, shopping centres close down (there are too many) and then become brownfields available for re-use. The CascadePrebendarski vrtovi centre opened in 2009 and closed in 2011 and business operations were not transparent. One negative consequence of shopping malls is the disappearance of smaller stores and crafts in the city centre. They have become "useless" and unprofitable. "Recent field research in Ilica, the most popular shopping street in Zagreb, has revealed 161 closed-down businesses (almost half of them retail businesses)" (Jakovčić, 2009).

Shopping malls are always accompanied by underground parking garages, seemingly good solutions for traffic in the city centre but in fact just additional profit for investors. Although they "hide" cars from public sight and are therefore a better solution than parking lots, they also shrink public space and cause traffic congestion. Big competition also leads to empty garages and financial losses. For example, the garage in Varšavska Street means less business for the garage at Tuškanac. Another example is the garage in Kvaternik Square which may help the drivers but is inconvenient for pedestrian circulation around the square. Reconstruction of this square has received a lot of criticism because it has become an empty plateau, where people do not linger as much as before. According to Uzelac (in Matejčić, 2008), current trends in Zagreb are contrary to urban planning processes in the world: here, cars are given priority over pedestrians.

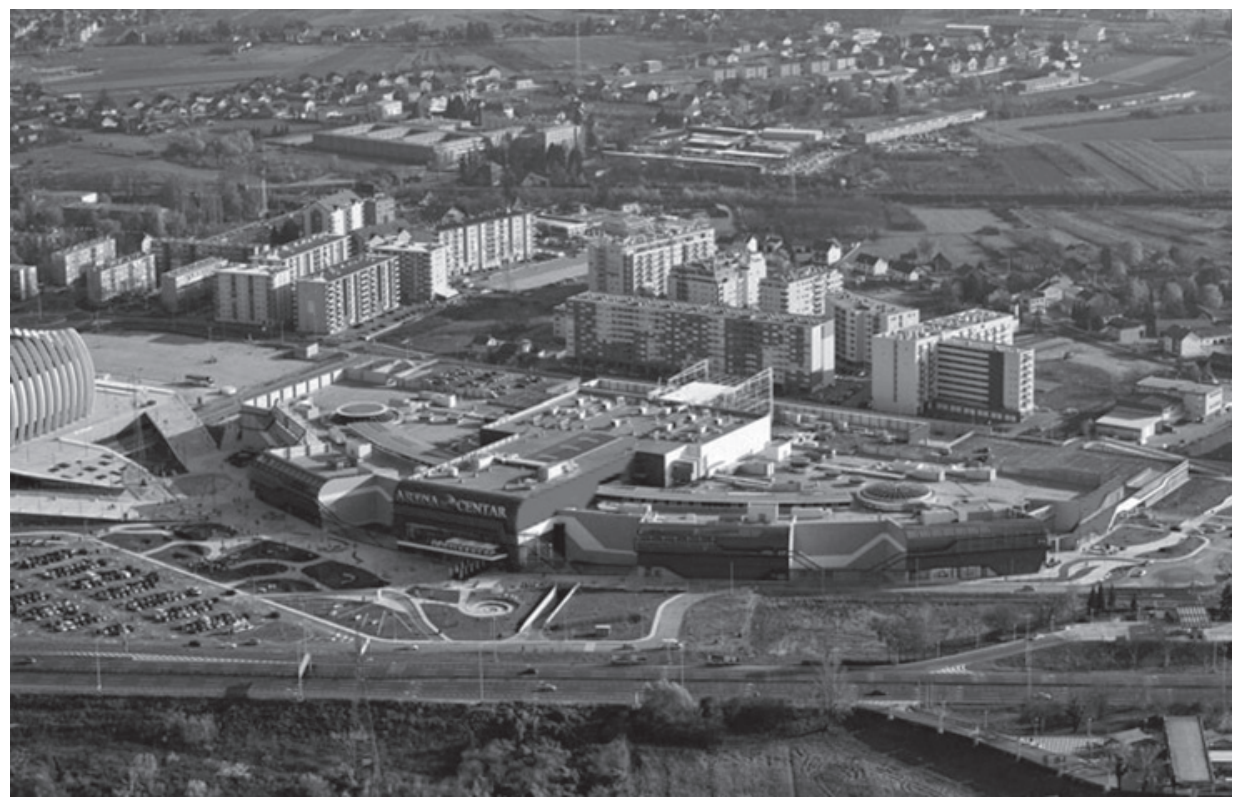

Fig. 5 Arena Center on the edge of Zagreb

Sl. 5. Arena centar na (jugozapadnom) rubu Zagreba

Source: http://www.mucic.hr/novi/images/stories/slike/2010/arena_centar_zagreb.jpg

\footnotetext{
${ }^{9}$ Shrinking of public space is evident in Flower Square where two historical buildings were pulled down and part of Varšavska Street turned into the underground parking garage to accommodate a private shopping mall, Cvjetni.
} 
The examples in Zagreb (high-rise towers, shopping malls and underground parking garages) are not examples of genuine urban renewal but random, incomplete and chaotic urban transformations. They are only part of a wider process of urban renewal, which has not been systematically carried out in the transition period. True urban renewal should be based on the clear and precise study of what Zagreb needs in terms of renovation and priority. Short-term, random solutions cannot replace a carefully thought-out, long-term urban development strategy. "In town planning, for many years now, there has been a string of illogical decisions. The best municipal land has been allocated to shopping malls, offices and businesses. Residential projects have ended up in less convenient and attractive locations" (Jukić et al., 2011, 43).

It is also worth pointing out that the lack of urban planning does not benefit any social actors. Shrinking public space is becoming less accessible to citizens for everyday use and leisure time. In new housing estates the infrastructure is poor (few facilities or services). Economic actors, e.g. small investors, often suffer losses without detailed study of projects which would calculate their profitability. Professionals/experts and their knowledge are pushed aside, their expertise underestimated or "modified" to suit the investors' requests. The final product is then of inferior quality and problems multiply. Political actors lose credibility because they occasionally abuse their power and yet cannot control spatial changes. Mostly they join forces with investors and ignore other social actors (professional and civil actors). Public-private partnership has not been adequately or sufficiently applied and has not given satisfactory results.

\section{CONCLUSION}

During socialism, urban space and urban planning were clearly defined concepts and there was a tendency to preserve space, to avoid megalomania in building. Urban planning was guided by strict principles of building and a clear definition of public space as open and accessible to everyone. Primary and secondary infrastructure accompanied new housing developments. Since the 1990s and especially since 2000 onwards, this attitude has changed. Space is not regarded as something worth protecting but something worth a lot of money. In Zagreb the idea of public interest or the quality of housing is almost non-existent. The authorities do not seem to be aware of the fact that urban development of the city also initiates economic development and strengthens the public sector.

Following trends from the 1990s, the lack of planning in a wider metropolitan area caused uncontrolled flow to Zagreb County and small urban centres within it. In the second decade of the transition, however, trends reversed and people returned to suburban areas, within the tram zone. Scattered, "patchwork" residential developments (sometimes isolated, edge of the city locations) make the City of Zagreb very busy and crowded, whereas the County settlement network is only attractive in some places. Thus, the socialist legacy continues: the central position of Zagreb has once again been cemented.

All things considered, the conclusion is inevitable: irretrievable loss of space, especially public space, as a consequence of transition changes. Private interest has overpowered public interest and therefore, public space is crammed with residential or commercial developments. So it is not surprising that the citizens of Zagreb constantly ask for more kindergartens, schools or playgrounds. When public space is shrinking and being unwisely used up, new housing developments become a paradox. They no longer serve their purpose because there is no place for new schools, kindergartens, sport and recreation facilities, and parks. The old, existing facilities are put under additional pressure. Both residential and commercial developments still suffer from "transition diseases". It is true that transition was very advantageous for some social actors but after two decades it is time for the citizens and the City of Zagreb to enjoy some benefits, too. 
Research findings show an obvious misbalance of power and influence among urban actors in Croatia. Some are very powerful (economic and political actors), some less powerful and sometimes completely useless (civil and professional actors). This is not problematic per se because it is a normal part of social reality, but when it endangers public interest and public space, it is a different matter. Public participation in planning and decision-making processes related to the environment has been weak for some time now. Non-government organizations (NGOs), a new type of actors, have come into conflict with economic actors. They are critical of the present situation and try to introduce some changes in the decision-making and increase participation of the public. They are therefore "regulators" of democracy. The city government manage urban development of Zagreb weakly and non-transparently, favouring private investors. Some professionals forget their code of practice and by taking the side of investors become responsible for scattered, "patchwork" residential and commercial developments. Decision-making procedures are non-transparent and there are frequent alterations of the Master Plan of the City of Zagreb, which is not acceptable because it is the main strategic planning document. Spatial planning should be given the care and appreciation it deserves. This also includes transparent participation of the public (experts and civil actors) in practical and legal matters.

Bearing in mind everything mentioned so far, it is essential to correct the mistakes of the transition period and give a more prominent role in town management to professional and civil actors. Today's random and chaotic building in locations lacking the necessary facilities certainly does not facilitate their mission. Interdisciplinary urban planning does not exist either and one can talk about the so-called "death of urbanism" during transition. Partial urban planning neglects the complete appearance of the city and limits the concept of housing to residential housing in the hands of private investors, thus lowering the quality of housing for most residents. On the other hand, attractive locations in the city are given to economic actors for commercial developments. To sum up, both assumptions have been confirmed: the city centre is dominated by commercial developments while the periphery, which is rather unattractive, is left to residential (mostly social) developments. It is clear that public interest is forgotten in urban planning. It is subject to interests of influential economic and political actors who have the power and the money.

\section{REFERENCES}

Bassand, M., 2001: Pour un renouveau de la sociologie urbaine: onze thèses, Urbanisme, 10 (321), 84-88.

Carmon, N., 1999: Three Generations of Urban Renewal Policies: Analysis and Policy Implications, Geoforum, 30, 145-158.

Čaldarović, O., 2011: Urban society at the beginning of the 21st Century. Zagreb: Jesenski i Turk and Croatian Sociological Society.

Dimitrovska Andrews, K., Ploštajner, Z., 2001: Local Effects of Transformation Processes in Slovenia, Informationene zur Raumentwicklung, 7/8, 435-449.

European Charter on Housing, Review of Social Policy, 14 (3-4), 391-399, 2007.

Gregson, N., 1995: And Now It's All Consumption? Progress in Human Geography, 19(1), 135-141.

Hamilton, I., Dimitrovska Andrews K. \& Pichler.Milanović, N. (Eds.), 2005: Transformation of Cities in Central and Eastern Europe. Tokyo; New York; Paris, United Nations University Press.

Hodžić, A., 2005: Social restructuring and new social context. Sociology of the Village 43, 169 (3), 497-525.

Jakovčić, M., 2009: Shopping Centre as a Brand. Geografija.hr. http://www.geografija.hr/clanci/1472/trgovackicentar-kao-brand (4 March, 2012).

Jukić, T., Mlinar I., Smokvina, M., 2011: Zagreb - Housing in the City and Residential Areas, University in Zagreb, Zagreb, Faculty of Architecture. 
Kuvačić, I., 1990: Functionalism in sociology. Zagreb: Naprijed.

Low, S. M., 1992: Symbolic Ties That Bind: Place Attachment in the Plaza, in: Place Attachment. (Eds. Altman, I and Low, S.M.), New York, Plenum Press, 165-185.

Matejčić, B., 2008: Impersonal Surface Instead of Square. Vjesnik, 18.

Parsons, T., 1966: Societies: Evolutionary and Comparative Perspectives. Englewood Cliffs, NJ: Prentice-Hall.

Pichler-Milanović, N., 2001: Urban Housing Markets in Central and Eastern Europe: Convergence, Divergence or Policy Collapse, European Journal of Housing Policy, 1 (2), 135-187.

Pušić, Lj. 2015: City, Society, Space. City Sociology. Beograd, Zavod za udžbenike, 506 pp.

Seferagić, D., 1988: Quality of life and new residential settlements. Zagreb: Croatian Sociological Association.

Seferagić, D., 2005: Pyramid network of towns, Sociology of the Village, 43(169 (3)), 579-616.

Sić, M., 2007: Spatial and Functional Changes in Recent Urban Development of Zagreb, Dela 27, 5-15.

Smith, N., 2002: New Globalism, New Urbanism: Gentrification as Global Urban Strategy, Antipode, 34(3), 427-450.

Svirčić Gotovac, A., 2006: The quality of living in the settlements network in Croatia, Sociology and Space, 44, 171 (1), 105-126.

Svirčić Gotovac, A., 2010: Ongoing Processes of Revitalisation and Gentrification in Zagreb, Sociology and Space, 48, 187(2), 197-221.

Svirčić Gotovac, A., 2012: Actors of Social Changes in Space (2007-2011), in: Actors of Social Changes in Space; Transformation of Space and Quality of Life in Croatia. (Eds. Svirčić Gotovac, A. and Zlatar, J.) Zagreb: Institute for Social Research, 13-27.

Svirčić Gotovac, A. (2015): New housing estates in the settlement network of Zagreb - community infrastructure. In: Svirčić Gotovac, A. and Zlatar, J. (Eds). The Quality of Living in New Housing Estates in the Settlement Network of Zagreb. Institute for Social Resarch in Zagreb, Biblioteka Znanost i društvo, knjiga 37 (Edition Science and Society, book 37). (in the process of publishing)

Sykora, L., 1994: Local Urban Restructuring as a Mirror of Globalization Processes: Prague in the 1990s, Urban Studies, 7 (31), 1149-1166.

Toš, I. and students, 2012: Participation in the Processes of Built Environment Development. Report on Field Research, Zagreb, Faculty of Humanities and Social Sciences.

Voyce, M., 2006: Shopping Malls in Australia. The End of Public Space and the Rise of "Consumerist Citizen ship", Journal of Sociology, 42(3), 269-286.

Vresk, M., 2002: Development of urban systems in the world, Zagreb, Školska knjiga.

Vujović, S., 2005: Urban sociology. Beograd: Zavod za udžbenike i nastavna sredstva.

Vujović, S. (2012): Actors of entrepreneurial towns in the game of power - the example of Serbia. In: Actors of Social Changes in Space; Transformation of Space and Quality of Life in Croatia. (Eds. Svirčić Gotovac, A. and Zlatar, J.) Zagreb: Institute for Social Research, 51-62.

Zlatar, J., 2013: Urban Transformations of Contemporary Zagreb, Zagreb, Plejada and Institute for Social Research in Zagreb.

Zlatar, J., 2014: City Profile. Zagreb Cities. The International Journal of Urban Policy and Planning. 39, 144-155.

\section{SOURCES}

Agency for Government Real Estate - www.apn.hr (16th May, 2015)

Croatian Parliament: Strategy of Sustainable Development in Croatia, http://narodne-novine.nn.hr/clanci/ sluzbeni/2009_03_30_658.html (5 December 2013) 
http://photos.wikimapia.org/p/00/03/65/46/82_full.jpg (15 September, 2013)

http://www.mucic.hr/novi/images/stories/slike/2010/arena_centar_zagreb.jpg (13 September, 2013)

http://foto.drusany.com/wp-content/uploads/2013/07/Ban-centar-Panorama.jpg (14 September, 2013)

Jutarnji list, http://www.vecernji.hr/zg-vijesti/nova-prilika-za-zivot-u-sopnici-jelkovec-jos-300-stanova-unajam-od-160-eura-957414 (25 May, 2015).

ZagrebPlan 2013: Zagreb Development Strategy. Strategic Development Orientation until the End of the Year, Zagreb, City of Zagreb development strategy.

\title{
SAŽETAK
}

\section{Urbani procesi u Zagrebu. Stambena i poslovna gradnja}

\author{
Anđelina Svirčić Gotovac, Jelena Zlatar
}

U radu se predstavljaju neki od specifičnijih urbanih procesa koji su intenzivno obilježili prostor i identitet grada Zagreba u posljednjih desetak godina. Izlažu se neki relevantniji rezultati urbanosocioloških istraživanja provedenih u Institutu za društvena istraživanja u Zagrebu iz nekoliko projekata od 2007. do 2015. U tranzicijskom razdoblju glavni je grad Hrvatske doživio značajne fizičke i društvene transformacije vidljive kroz proces gradnje, prije svega one stambenoga tipa, ali i poslovnoga. Opseg privatne stambene gradnje tolik je da neki izvori govore o velikom višku stanova u Zagrebu kao njegovoj posljedici. Socijalno je stanovanje, s druge strane, zanemareno i iako u obliku tzv. POS-a postoji, u Zagrebu je u odnosu na privatni tip nedovoljno prisutno. Stoga je vrlo važno istaknuti sve posljedice trenutačnog stanja kako za kvalitetu života u Zagrebu tako i za njegov daljnji urbanistički razvoj. Novi urbani akeri koji se pojavljuju u tranzicijskom kontekstu, prije svega politički i ekonomski, imaju veću moć djelovanja te diktiraju prostorni i urbani razvoj, dok je primjerice utjecaj stručnih i civilnih aktera na urbani razvoj značajno manji.

Osnovna je hipoteza ovoga rada da ne postoji strateško i dugoročno planiranje razvoja Zagreba. Postavljena je i hipoteza da su najatraktivniji gradski dijelovi i lokacije prepušteni komercijalnoj izgradnji, primjerice poslovnih i stambenih zgrada, trgovačkih centara i podzemnih garaža, dok manje atraktivni dobivaju socijalnu ili javnu namjenu. Daljnjom analizom rezultata istraživanja dobivenih upotrebom kvalitativnih i kvantitivnih metoda (anketa i polustrukturirani intervjui) prikazani su primjeri komercijalne i rezidencijalne gradnje na prostoru grada Zagreba. Ti primjeri procesa urbane transformacije predstavljeni su i u odnosu na pojedine dijelove grada kao što su strogo središte (gradska jezgra) i rubovi (periferija) grada. Analizirani su primjerice trgovački centri i podzemne garaže u središtu Zagreba, od kojih većina, kako se pokazalo, nije ni urbanistički ni svojom namjenom ispunila početna očekivanja, pa na takvim parcijalnim primjerima procese tzv. urbane obnove ili gentrifikacije ne možemo ni definirati u zagrebačkom kontekstu. Posebno se analizirao primjer zagrebačkoga Cvjetnog trga kroz proces gentrifikacije i izgradnje multfunkcionalnog centra Cvjetni, koji je postao prototip tranzicijske i urbane transformacije koja jasno pokazuje u kojem se smjeru Zagreb urbanistički razvija te planira razvijati. Tim se primjerom također pokazuje da su najviše zadovoljeni interesi novih urbanih aktera (političkih i ekonomskih) s njihovom tzv. novom modernizacijom grada, koja se desetak godina poslije pokazuje promašenom. Najveći joj je nedostatak što je prouzrokovala izrazito narušavanje javnih prostora, čime se središte grada nepotrebno opteretilo. Pretjerano pridavanje važnosti, gotovo robovanje, funkciji prometa, posebno automobilskoga, koji se takvim razvojem gradske jezgre 
povećao, svakako ne ide ukorak sa suvremenim razvojnim tendencijama europskih gradskih središta. U njima se naglašava važnost očuvanja jezgara u javnome i društveno-korisnom smislu, prije svega kulturnoga naslijeđa i baštine te razvijenog turizma, što u Zagrebu nije slučaj.

Usporedno s gradskom jezgrom jednako se, ako ne i radikalnije, transformiraju periferija i rubovi grada. Dugogodišnja gradnja stambenih i poslovnih lokacija po principu točkastog planiranja dovela je do fenomena preizgrađenosti, naročito stambenih zgrada. Neki izvore tvrde da je riječ o čak 20.000 stanova viška koji sada na tržištu nekretnina ne mogu postići potrebnu cijenu, ali ni pronaći kupce. S druge strane, socijalna gradnja (tzv. POS) zanemarena je te se na primjerima izgrađenih POS-ovih naselja kao što su Špansko, Vrbani III ili čak Sopnica-Jekovec pokazuje da stanovnici trebaju takav tip brige za segment stanovanja jer su komercijalni uvjeti kupnje vlastitog stana mnogim stanovnicima nedostupni. Bez sudjelovanja grada ili države u takvim projektima situacija na stambenom tržištu te u stambenoj politici općenito neće se značajnije poboljšati.

Osim toga i kvaliteta života u istraživanim novostambenim naseljima i na novim lokacijama pokazala se, prema terenskom istraživanju iz 2014., relativno nezadovoljavajućom i na primarnoj i na sekundarnoj razini opremljenosti. Opremljenost susjedstva ili neposredne životne okoline pokazala se manjkavom na većini istraživanih lokacija te iznijela na vidjelo nezadovoljstvo stanovnika životom u naseljima koja nemaju ni osnovnu ni javnu infrastrukturu potrebnu za svakodnevno funkcioniranje, kao što su vrtići, škole, zelene površine, parkovi itd. Zanimljivo je također da su najzadovoljniji upravo stanovnici u POS-ovim naseljima te da u njima mogu zadovoljiti većinu svojih svakodnevnih potreba. Na ostalim novostambenim lokacijama pak novi stanari stvaraju dodatni pritisak na starija naselja i njihovu infrastrukturu, što ni u kojem slučaju nije dugoročno održivo rješenje.

Prema svemu navedenome, u radu se zaključuje da su početne hipoteze potvrđene te da je smisao urbane politike prije svega javni interes, a ne samo privatni. Nastavi li se urbana transformacija Zagreba odvijati na ovakav način, može se očekivati da će i buduća istraživanja pokazivati opadanje razine kvalitete života, što bi trebalo zabrinuti aktere urbane politike. Zagreb će na takav način teško izaći iz granica postsocijalističkoga i tranzicijskoga grada te izbjeći sve nedostatke koje takav kontekst, koji se u radu detaljno analizira, donosi.

Received (Primljeno): 2014-11-12

Accepted (Prihvaćeno): 2015-06-16

Anđelina Svirčić Gotovac, PhD

Institute for Social Research in Zagreb

Amruševa 8/II, Zagreb, Hrvatska

svircic@idi.hr

Jelena Zlatar, PhD

Institute for Social Research in Zagreb Amruševa 8/II, 10000 Zagreb, Hrvatska jelena@idi.hr 